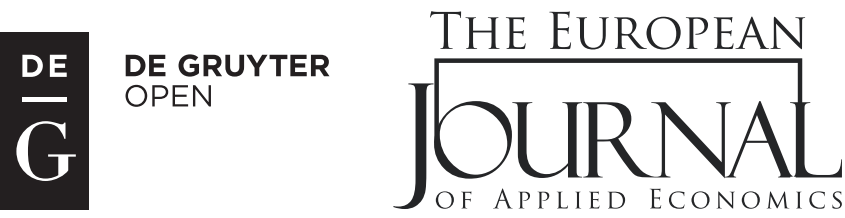

EJAE 2017, 14(2): 58-69

ISSN 2406-2588

UDK: 658.14

334.72:330.14

DOI: $10.5937 /$ ejae14-14391

Original paper/Originalni naučni rad

\title{
THE ROLE OF VENTURE CAPITAL IN THE DEVELOPMENT OF THE SME SECTOR
}

\author{
Irena Đalić ${ }^{1 *}$, Svetlana Terzić ${ }^{1}$, Boris Novarlić \\ ${ }^{1}$ University of East Sarajevo, Faculty of Transport and Traffic Engineering Doboj, \\ Doboj, Bosnia and Herzegovina \\ KP,Progres" a.d. Doboj, \\ Doboj, Bosnia and Herzegovina
}

\begin{abstract}
:
Entrepreneurs as well as SMEs, regularly face the problem concerning access to finance. Entrepreneurial firms face two major problems. The first concerns access to finance, which places particular restraint on a firm's ability to increase the level of technology in their business. The second problem is access to know-how. The subject of this survey is the role of venture capital funds in the development of newly established companies and its potential application in the Republic of Srpska. In the Anglo-Saxon countries, newly emerged enterprises that start their business from scratch are called start-up companies. The assumption that venture capital financing can give newly established companies bigger chances of succeeding in their start-up stage is made. It is known that our companies provide capital through bank loans which have lately become less available especially to early stage businesses. Therefore, in order for companies to achieve their goals and develop their projects they must finance their business through venture capital funds that are willing to invest in start-up companies.
\end{abstract}

\section{Keywords:}

venture capital,

SMEs, entrepreneurship, employment, innovation.

\section{INTRODUCTION}

The SME (small and medium-sized enterprises) sector is important for the global economy mainly because SMEs are relatively flexible; they easily adapt to the changing business environment, and these businesses, when compared with big corporate entities, require less financial support. Starting a small and medium-sized business is relatively cheap and simple when compared to starting a big company (Steingold, 2006). SMEs are also significant sources of work. Thus, they help in the fight against the unemployment. Because of all these mentioned qualities, high-income countries are providing considerable support to the SMEs sector. This is seen through the SMEs share in the total enterprise population which ranges from $99.5 \%$ in Japan to $99.8 \%$ in the EU and the USA. In the EU, SMEs account of total employment in the non-financial sector is $67.0 \%$, in the USA $52.4 \%$, and in Japan $86.6 \%$ (European Commission, 2015). 
Young firms in particular are faced with this problem in the early stage of business. Venture capital funds differ from another fundings in the way that venture capitalists support risky start-up businesses that deal with some sorts of new technologies. Venture capital can be defined simply as risk-equity investments in newly established entrepreneurial firms (Klonowski, 2010).

When it comes to SMEs, it is crucial to find a way to improve access to the wide range of external sources of finance. Venture capital funds give entrepreneurial companies the opportunity to finance their development projects, which leads to the increase in competitiveness, economic growth and total employment. Therefore, the aim of this research is to give the answer to the following question: Do newly established firms in the Republic of Srpska have the support of venture capital funds in their early stages of business?

To be more precise, the following question should be asked: Has SMEs managers' perception of development projects funding by venture capital in the Republic of Srpska changed since the previous survey conducted in 2013 ?

\section{LITERATURE REVIEW}

Entrepreneurs and SMEs are crucial factors affecting economic growth in both developed countries and those in transition. Peter Drucker and George Gilder both believe it is important not only to combine resources in a new way, but also to create new ones (Drucker, 1991; Gilder, 1986). Entrepreneurship, according to the traditional definition, is the set of activities carried out to combine resources with the intent of profiting. Thus, to maintain and earn profit it is neccessary to find the most favorable combination of resources - the one that saves scarce resources and increases the volume of production (Vukmirović, 2006). The term enterpreneurship also includes a person who creates a new product or offers service under conditions of extreme uncertainty (Ries, 2011).

In developed countries SMEs are the sources of economic growth. Entrepreneurial firms provide many new jobs every year. Joseph Shumpeter, as well, thought that innovation and entrepreneurship occupy a decisive role in economic development. He believed that economic growth occurs when a critical mass of entrepreneurs start new business activities. (Shumpeter, 1975). The state and entrepreneurships as well need to realise how entrepreneurship is important for development and, therefore, they need to create programs that motivate entrepreneurs to create innovative projects spurring their business growth as well as economy (Estay et al., 2013).

When selecting start-ups to fund, venture capitalists analyze the ability of the founding team, their managerial abilities, staying power and familiarity with the market. Naturally, venture capitalists tend to fund entrepreneurs that appear to have more skills (Zhang, 2011). To be a successful entrepreneur, the key is to have a business idea. Future entrepreneurs need to be truly creative, understand the market and, most importantly, be self-confident. Their willpower must be stronger than any risk. It is neccessary to work hard and enjoy the job in order to become a great entrepreneur (Tobin, 2012). The business "rewards" for these entrepreneurs are primarily in the form of personal independence and the business cash flow (Aulet, 2013).

The common problem that entrepreneurs face is raising money that will ensure the greatest success in business compared to the costs that these sources require. In developed countries micro, small and middle-sized companies fixate on numerous funding sources such as bank loans, leasing, factoring, mezzanine financing, stock exchanges, and venture capital (Petković \& Berberović, 2013). Venture capital funds are types of funds that are internationally known as "Private Equity Fund" and "Venture 
Capital Fund". However, it is important to distinguish between these two terms. Equity Fund is a broader term than Venture Capital Fund. Venture Capital Fund is, by default, regarded as investments made during the launch stages of a business, while Private Equity Fund includes Venture Capital and takeover. Venture capital funds are defined as funds that invest in companies in exchange for a share in the property. Those are firms that pool money from private investors and expect a high annual return (typically $20 \%$ to $40 \%$ ) on their investment (Awe, 2006). Many venture capital firms will not consider a deal that involves less than $\$ 3$ million (Harper, 2005).

Venture capital investments are directed at companies that are not able to pay interests on debts or dividends on equity, and their capital gains are used for further business transactions (Cumming \& Johan, 2014). Once VCs invest in a successful company, they usually continue their investing in the company's later stages of development. In modern developed markets, such as the US and the EU market, there is a large number of venture capital funds that are willing to invest in high-risk enterprises. Because of this, companies are willing to pay $10 \%$ to $14 \%$ of the premium in the form of a discount on the assessment in order to receive money from renowned venture capital funds giving up less prominent VCs investment proposals (Park \& Steensma, 2012).

Venture Capital Fund usually consists of at least 10 to 20 partners, so the capital collection is a long and difficult process (Romans, 2013). Venture capital funds operate in a cycle (Keuschnigg \& Nielsen, 2001). VCs collect private investors' capital and invest in businesses expecting high annual returns. When they get the returns, that capital is invested again in new businesses. The VC context has four different attributes. First, VCs invest in newly-established companies and these investments are highly uncertain. Second, VC firms primarily rely on applying knowledge resources which they use to select and coach portfolio companies. Third, VCs are not necessarily diversified, which means they are typically single unit firms. And fourth, despite the fact that the research indicates that VCs prefer low levels of diversification in the context of uncertainty, not much about the actual relationship between these diversification levels and performance is known (Matusik \& Fitza, 2012).

Depending on the company's stage of development, there are a few types of VCs investments. In literature, different interpretations of business development stages can be found. The three most frequently mentioned stages are: early stage, expansion stage and later stage (Schertler, 2006). However, according to Mathonet and Meyer there are four stages of development and those are: seed stage or start-up stage, early stage, balance stage and later stage (Mathonet \& Meyer, 2007). According to Golis, Mooney and Richardson, the type and the availability of funds depend also on the stage of development (Golis et al., 2009). When investing in companies, VCs analyze several factors, such as: the market characteristics, financial return potential, the new venture's business plan and the ability of management (Grünhagen, 2008).

Many studies show that VC funding has proven successful in developed countries. Venture capital funds have managed to fill the gap in the financial marketplace since they are willing to invest in risky ventures in their start-up stage (Harper, 2005). Professor Christian Keuschnigg proved in his work Venture Capital Backed Growth that VCs contribute to rapid growth of emerging businesses (Keuschingg, 2002). Also, Astrid Romain and Bruno van Pottelsberghe de la Potterie, who dealt with the macroeconomic impact on venture capital funds (Romain \& Van Pottelsberghe de la Potterie, 2004), proved that VCs have a positive impact on macroeconomic indicators. Studies have shown that venture capitalists mostly invest in small countries in which some renowned companies are founded. These funds invest more in companies dealing with IT, mechanical engineering and biotechnology than in other industries (Schertler \& Tykvová, 2009). There are about 800 venture capital funds in the US. 
In 2010 these funds invested about $\$ 179$ billion in 3,276 companies (Barringer \& Ireland, 2011). Alexander Popov and Peter Roosenboom explored the relationship between venture capital and innovation in the period from 1990 to 2005 in the whole Europe. They have documented an increase of 10\% of patented innovations under the influence of venture capital investments (Popov \& Roosenboom, 2012).

The role of venture capital in the development of entrepreneurship and the economy in general has been seen during the mid 70s in Germany when the country provided a considerable support to the development of venture capital market, which was the reason why it has been criticized by major banks. Also, Scotland and Israel are examples of how venture capital is crucial for the economy. These countries have developed venture capital policies that differ from the traditional approach to this way of funding (Rosiello et al., 2011).

According to Scherlter's survey VCs affect GDP and its increase. Scherlter's research included 16 European countries. In all of these countries, a significant innovative business growth rate has been achieved as a consequence of the development of venture capital funds, which allowed companies dealing with high-risk technologies to rapidly develop and employ more workers. According to the survey, mainly the government support contributed to the formation of venture capital funds in these European countries. This support had a great influence on the conditions in which emerging businesses or start-ups dealing with high-tech, operated (Scherlter, 2006). According to Metrick and Yasuda, half of total US venture capital is invested in companies operating in the Silicon Valley and in the area around Boston. This is understandable because many companies dealing with the development of new technologies are operating in these two regions, which is a high-risk job for investors considering the high degree of uncertainty surrounding the process of commercialization of such new technologies (Metrick \& Yasuda, 2011). In 2002, a record in venture capital investments has been set when venture capitalists invested $\$ 120$ billion. That amount dropped in the following years, but it is still at the highest level in the world and is about $\$ 40$ to $\$ 50$ billion per year (Erić et al., 2012). In addition to innovation and clever ideas, start-up entrepreneurs need to have access to external sources of financing. When the business environment supports creativity, innovation and commercialization, companies have bigger chances of success (Hisrich et al., 2016).

\section{RESEARCH}

In this paper, the role of venture capital in the early stage of start-up businesses, as well as the interest and readiness of SMEs for VC investments in the Republic of Srpska, has been studied. The topic of the research is theoretical and empirical analysis of the role of VC in the new companies' early business stages in developed countries, and the possibility of applying the results of the research about VC investment to companies in the Republic of Srpska.

The research was conducted by simple random sampling, collecting responses to the questionnaires with close-ended questions, multiple choice questions as well as open-ended questions.

Quantitative research was conducted in the period from mid-January 2016 to mid-April 2016. It included 106 companies from the whole territory of the Republic of Srpska and was conducted in 27 municipalities: Banja Luka (20), Derventa (15), Doboj (12), Modriča (8), Prnjavor (6), Bijeljina (6), Laktaši (6), Prijedor (4), Čelinac (3), Trebinje (3), Novi Grad (3), Gradiška (2), Brod (2), Teslić (2), Pale (2), Šamac (1), Istočna Ilidža (1), Istočno Sarajevo (1), Kozarska Dubica (1), Ljubinje (1), Mrkonjić Grad (1), Pelagićevo (1), Srbac (1), Donji Žabar (1), Istočno Novo Sarajevo (1), Ribnik (1), Obudovac (1). The research included 32 micro, 72 small and medium-sized enterprises and 2 big companies. 
Similar research was conducted in 2013 (Petković et al., 2016; Hisrich, 2016) and these two surveys are compared to see if the situation has improved.

\section{Limitations of the reserach}

During the research we came across a number of limitations. We have to state that one of the biggest limitations of this research are very modest financial abilities, which is why we were unable to conduct a larger and more detailed research on the whole territory of the Republic of Srpska. The research was conducted on a small scale in relation to the size of the statistical weight (9,325 companies). According to the Intermediary Agency for IT and financial services (APIF) at the end of 2014, 9,325 companies have submitted required financial statements and we will take this information as relevant to the size of the statistical weight. At the same time, this is the latest data we were able to reach (APIF, 2014).

Perhaps the biggest problem we faced during the course of this research was acquiring data held by the institutions in charge of monitoring the economic situation in the Republic of Srpska. This data may vary depending on the source.

The companies poorly responded to invitations to take part in this research. Was it because the topic of the research was still new here, or maybe, people just did not want to participate in studies? The thing that we can conclude is that company owners and managers do not show a great desire for cooperation with the academic community conducting researches.

\section{Research Results}

The questionnaire we based our research on consists of three parts. The first part refers to some general information about the companies that participated in the research. The second part represents the information on venture capital funds, and in this section we tried to find out how our companies, in general, are familiar with VCs and the methods of approaching them. Finally, the third part refers to the willingness of the companies to be funded by venture capital funds.

\section{General information about the companies}

Given the fact that the territory of the Republic of Srpska was the subject of our research, we managed to encompass the whole mentioned territory. We chose random companies by sending a questionnaire to their e-mail addresses we found in address books. Most companies that took part in the research are form the Banja Luka and Doboj region. These data are shown in Table 1. 


\begin{tabular}{|c|c|c|}
\hline No. & Head Office & Number of units \\
\hline 1. & Banja Luka & 20 \\
\hline 2. & Derventa & 15 \\
\hline 3. & Doboj & 13 \\
\hline 4. & Modriča & 8 \\
\hline 5. & Prnjavor & 6 \\
\hline 6. & Bijeljina & 6 \\
\hline 7. & Laktaši & 6 \\
\hline 8. & Prijedor & 3 \\
\hline 9. & Čelinac & 3 \\
\hline 10. & Trebinje & 3 \\
\hline 11. & Novi Grad & 3 \\
\hline 12. & Gradiška & 2 \\
\hline 13. & Teslić & 2 \\
\hline 14. & Pale & 2 \\
\hline 15. & Brod & 1 \\
\hline 16. & Šamac & 1 \\
\hline 17. & Istočna Ilidža & 1 \\
\hline 18. & Istočno Sarajevo & 1 \\
\hline 19. & Kozarska Dubica & 1 \\
\hline 20. & Ljubinje & 1 \\
\hline 21. & Mrkonjić Grad & 1 \\
\hline 22. & Pelagićevo & 1 \\
\hline 23. & Srbac & 1 \\
\hline 24. & Donji Žabar & 1 \\
\hline 25. & Istočno Novo Sarajevo & 1 \\
\hline 26. & Ribnik & 1 \\
\hline 27. & Obudovac & 1 \\
\hline 28. & Gacko & 1 \\
\hline & & 106 \\
\hline
\end{tabular}

Table 1. Classifying the companies from the sample according to their head offices

If we look at the sample, taking into consideration the years when the companies were established, we can conclude that the "average age" of selected companies is 15 years, as well as that $50 \%$ of them were established prior to 1998 and vice versa. Most of the companies were established in 2001 ( 9 of them). The oldest company was founded in 1950, while the youngest was founded in 2013. 
According to the form of organization, most common are companies that are registered as limited companies (hereinafter Ltd.). They are followed by joint-stock companies and sole proprietors. This is provided in detail in Table 2.

\begin{tabular}{rccc}
\hline No. & Form of organization & No. of companies & \% of the total sample \\
\hline $\mathbf{1}$. & Ltd. & 85 & $80.19 \%$ \\
\hline $\mathbf{2}$ & Joint-stock company & 10 & $9.43 \%$ \\
\hline $\mathbf{3}$. & Sole proprietor & 4 & $3.77 \%$ \\
\hline $\mathbf{4}$. & General partnership & 1 & $0.94 \%$ \\
\hline $\mathbf{5}$. & Co-op & 2 & $1.89 \%$ \\
\hline $\mathbf{6}$. & State-owned enterprise & 4 & $3.77 \%$ \\
\hline TOTAL: & & $\mathbf{1 0 6}$ & $\mathbf{1 0 0} \%$ \\
\hline
\end{tabular}

Table 2. Form of organization

Therefore, Table 2 shows the companies' form of organization. Here we can see that 85 companies are registered as limited companies. These companies accounted for $80.19 \%$ of the sample that included 106 companies all together. Joint-stock companies accounted for $9.43 \%$ of the companies that participated in the research, and sole proprietors accounted for $3.77 \%$ of the sample, while co-ops and state-owned enterprises accounted for $1.89 \%$ and $3.77 \%$, respectively.

When looking at the ownership structure, it can be noticed that almost all companies from the sample are privately held, because 94 out of 106 companies (88.68\%) are 100\% privately held. Moreover, another 4 companies are partially private, while 8 companies are fully or partially state-owned.

When we talk about the type of businesses that the companies from our research do, statistically, over $41.51 \%$ of the companies are trading and food companies, while other business activities are less seen in the sample. Professional, scientific and technical services are provided by only 4 companies (3.77\%), while another 10 companies $(9.43 \%)$ are dealing with some kind of high technology, such as communications, renewable energy or computer engineering.

Our research included 3,178 employees. The number of employees in a certain company ranges from 1 to 250 . Out of 106 companies, 32 companies are micro entreprises meaning they employ less that ten people; 56 companies are small enterprises employing less than fifty people; 16 companies are medium-sized enterprises employing less that two hundred and fifty people; while 2 companies are in the group of large enterprises. These data are shown in Table 3.

\begin{tabular}{ccc}
\hline Company size & No. of units & \% of the sample \\
\hline MICRO & 32 & $30.19 \%$ \\
\hline SMALL & 56 & $52.83 \%$ \\
\hline MEDIUM-SIZED & 16 & $15.09 \%$ \\
\hline BIG & 2 & $1.89 \%$ \\
\hline
\end{tabular}

Table 3. Company size and number of employees 
Table 3 shows that companies from the sample are mostly micro, small and medium-sized enterprises $(98.11 \%)$.

The number of companies that have a website is 69 , while 37 companies do not own an active website. That means that the number of companies that have a web page is much higher $(65.09 \%)$ than the number of companies that do not have a website (34.91\%). When we compare these data with the survey which covered the same ground in 2013, we can see that the number of companies that have a web site has significantly increased (Hisrich et al., 2016). The research shows that slightly less than half of the companies that own a website receive orders via the internet (32 out of 69 enterprises), while $79.71 \%$ of them regularly update their website.

\section{Awareness levels on venture capital funds}

Prior to the research, most of the companies did not know what venture capital funds were. However, compared to a similar study from 2013 , when $87.1 \%$ of the sample did not know what these funds were (Petković et al., 2016), this number has decreased. The present research shows that the percentage has decreased to $65.99 \%$. In addition to this, many companies do not know how VCs work (80 enterprises, or $75.47 \%$ ). Thus, there is a large number of companies that do not know how they can access them (97 enterprises, or 91.51\%). However, we must note that the numbers concerning awareness levels have changed for the better since the research conducted in 2013 when almost $90 \%$ of respondents stated they did not know how VCs worked (Petković et al., 2016). The fact that only 5 enterprises (4.72\%) know some of VCs operating in the Balkans or worldwide proves that venture capital investments are here still unknown as sources of funding, while 101 enterprises (95.28\%) have never heard of a single venture capital fund. The companies mostly fund their business through bank loans or loans in combination with other sources ( 88 enterprises, or $83.02 \%$ ). The second most common source of funding is friends and family funding alone, or in combination with other sources of financing (23 enterprises, or $21.70 \%)$. The third most common source of finance is leasing (22 enterprises).

It should be noted that none of the companies that participated in our research provided their capital through venture capital funds. There is only 1 enterprise in the sample that financed its business activities through angel investments.

Our respondents' opinion is that VCs in the Republic of Srpska should be supported by the government (Ministry of Science and Technology and Ministry of Industry, Energy and Mining), while a much smaller number of respondents believe they should be supported by the universities. These opinions should be cautiously taken into account since respondents' awareness levels on venture capital funds are significantly low.

\section{Companies' readiness to access venture capital funds}

When we talk about technological equipment, we have noted that the companies have started to pay more attention to new technologies in their business ventures. The results form the 2013 survey show that $51.61 \%$ of the then-respondents used new technologies in their business ventures (Hisrich et al., 2016). This number has significantly increased since then as Table 4 shows.

Table 4 shows that $83.96 \%$, or 89 enterprises from the sample, are introducing new technologies; 15 enterprises responded that they do not introduce new technologies into their business ventures, 
while 2 enterprises did not provide an answer to this question. If these are the actual data, we have a good starting point for the formation of venture capital funds.

\begin{tabular}{cccc}
\hline $\begin{array}{c}\text { Do you regularly intro- } \\
\text { duce new technologies? }\end{array}$ & Number & $\%$ & Valid \% \\
\hline Yes & 89 & $83.96 \%$ & $85.58 \%$ \\
\hline No & 15 & $14.15 \%$ & $14.42 \%$ \\
\hline TOTAL & 104 & $98.11 \%$ & $100 \%$ \\
\hline No data & 2 & $1.89 \%$ & \\
\hline TOTAL & 106 & $100 \%$ & \\
\hline
\end{tabular}

Table 4. The introduction of new techology

Of all the companies that participated in the research only one company has applied for venture capital investment. The thing we considered the most important was to examine whether the companies in the Republic of Srpska were willing to finance their business activities through VCs. This research shows that 82 enterprises, or $77.36 \%$, are willing to fund their ventures through VCs, while 22 companies, or $20.75 \%$ are not willing to do that. There are 2 companies that gave no answer relating to the issue.

Finally, there has been a positive response to the following question: Are you going to show more interest in venture capital funding upon completing this questionnaire? Half of the respondents (51.89\%) said yes, however, a great many of them were uncertain (38.68\%) as Table 5 shows.

\begin{tabular}{ccc}
\hline Answer & No. & $\%$ \\
\hline Yes & 55 & $51.89 \%$ \\
\hline No & 10 & $9.43 \%$ \\
\hline I do not know & 41 & $38.68 \%$ \\
\hline Total & 106 & $100 \%$ \\
\hline
\end{tabular}

Table 5. Did the questionnaire arouse your interest in venture capital funds

We believe our research was successful, given that we were able to raise our participants' interest in venture capital funds. According to this we can conclude that it would be useful to establish venture capital funds in the Republic of Srpska.

\section{CONCLUSIONS}

The SMEs are important for the global economy mainly because they are relatively flexible, they easily adapt to the changing business environment, and these businesses, when compared with big corporate entities, require much less financial support. SMEs are also significant sources of work. Thus, they help in the fight against the unemployment. Because of all these mentioned qualities, high-income countries are providing considerable support to the SMEs sector. 
According to the points discussed in this paper, we see that entrepreneurs alone, without the access to external sources of finance, are not able to accomplish their projects. In order for a project to be implemented, it is necessary to find the best sources of funding. There is a wide range of sources from bank loans, microfinance, through credit guarantee funds, and finally, there are venture capital funds. We have seen that predominant source of funding here are bank loans (in our research $83.02 \%$ of the companies finance their business activities through the bank loans). Still, these sources of funding are becoming less favorable, especially for companies that are at the beginning of their development. Even when banks approve such loans, the return is very expensive for start-up companies. The conditions when applying for a loan are the same whether you apply as an already developed company or as a start-up.

The most common sources of early-stage businesses financing are venture capital funds. Unlike banks, venture capitalists are willing to invest in ventures during their start-up phase. VCs, of course, invest their money in such business ventures because they expect to achieve above-average high returns on their investments.

VCs usually invest in enterprises operating in rapidly-growing industries, such as information technology. Companies that are funded by VCs receive other kinds of support mainly in the domain of marketing, human resources management, business strategy, which means that venture capitalists offer entrepreneurs technical assistance in addition to capital. This way, companies can rapidly develop, employ workers, thus contributing to the global economic growth.

We analyzed some previously conducted studies, as well as data we collected in our own research, to test the hypothesis we set at the beginning of the research.

Our research shows that the companies ( $83.96 \%$ of the sample) regularly introduce new technology which is a good sign of the willingness to keep pace with the economy trends. Also, the research shows that they are willing to fund their ventures through VCs (77.36\% of the sample). Half of the companies (51.89\% of the sample) are going to focus more of their attention on venture capital funds.

According to this research and some previous studies, we can confirm our initial hypothesis, and conclude that newly-established companies that fund their early-stage business ventures through venture capital investments have greater chances of success.

In order to attract foreign and domestic investors, or newly-emerged venture capital funds, it is crucial to create a favorable business environment. In order for VCs to function, in the first place, we need to create a favorable tax system, which means that the state should have a role in the development of venture capital marketplace. Our research respondents belive that the government, and its ministries should provide the greatest support in the formation of venture capital funds in the Republic of Srpska. Therefore, there are many things that need to be done in order to create favorable conditions for the formation of venture capital funds in the Republic of Srpska.

\section{REFERENCES}

APIF. (2014). Registar finansijskih izveštaja. Retrieved June 08, 2017, from http://www.apif.net/index.php/registri/ registar-finansijskih-izvjestaja/rfi-wb-god-2014.html. In Serbian.

Aulet, B. (2013). Disciplined entrepreneurship: 24 steps to help entrepreneurs launch successful new ventures. Hoboken, New Jersey: John Wiley \& Sons.

Awe, S. C. (2006). The entrepreneur's information sourcebook: Charting the path to small business success. Westport, Conn: Libraries Unlimited. 
Barringer, B. R., \& Ireland, R. D. (2011). Entrepreneurship: Successfully launching new ventures. Upper Saddle River, N. J: Prentice Hall.

Cumming, D. J., \& Johan, S. A. (2014). Venture capital and private equity contracting: An international perspective. Amsterdam: Elsevier.

Drucker, P. (1991). Inovacije i preduzetništvo: praksa i principi. Beograd: Privredni pregled. In Serbian.

Erić, D., Beraha, I., Đuričin, S., Kecman, N., \& Jakišić, B. (2012). Finansiranje malih i srednjih preduzeća u Srbiji. Beograd: Institut ekonomskih nauka, Privredna komora Srbije. In Serbian.

Estay, C., Durrieu, F., \& Akhter, M. (2013). Entrepreneurship: From motivation to start-up. Journal of International Entrepreneurship, 11(3), 243-267.

European Commission. (2015). Annual report on European SMEs 2014/2015, SMEs start hiring again. Retrieved April 25, 2017, from https://publications.europa.eu/en/publication-detail/-/publication/7c9fbfe0-e044-11e58 fea-01aa75ed71a1.

Gilder, G. F. (1986). The spirit of enterprise. Harmondsworth: Penguin.

Golis, C. C., Mooney, P. D., \& Richardson, T. F. (2009). Enterprise and venture capital: A business builder's and investor's handbook. Crows Nest, N.S.W: Allen \& Unwin.

Grünhagen, M. (2008). The evolution of entrepreneurs' fundraising intentions: A multiple case study of financing processes in new ventures. Wiesbaden: Gabler.

Harper, S. C. (2005). Extraordinary entrepreneurship: The professional's guide to starting an exceptional enterprise. Hoboken: John Wiley \& Sons.

Hisrich R. D., Petković, S., Ramadani, V., \& Dana, L. (2016). Venture capital funds in transition countries: Insights from Bosnia and Herzegovina and Macedonia. Journal of Small Business and Enterprise Development, 23(2), 296-315. DOI: 10.1108/JSBED-06-2015-0078.

Keuschnigg, C. (2002). Venture capital backed growth. München: CESifo.

Keuschnigg, C., \& Nielsen, S. (2001). Public policy for venture capital. International Tax and Public Finance, $8(4), 557-572$.

Klonowski, D. (2010). The venture capital investment process: Principles and practice. New York: Palgrave Macmillan.

Mathonet, P.Y., \& Meyer, T. (2007). J-curve exposure: Managing a portfolio of venture capital and private equity funds. Chichester, England: Wiley \& Sons.

Matusik, S. F., Fitza, M. A. (2012). Diversification in the venture capital industry: leveraging knowledge under uncertainty. Strategic Management Journal, 33(4), 407-426. DOI: 10.1002/smj.1942.

Metrick, A., \& Yasuda, A. (2011). Venture capital and the finance of innovation. New York: Wiley.

Park, D. H., \& Steensma, K.H. (2012). When Does Corporate Venture Capital Add Value for New Ventures? Strategic Management Journal, 33(1), 1-22. DOI: 10.1002/smj.937.

Petković, S., Ateljević, J., \& Narić, I. (2016). Venture Capital Funds in Transition Countries: An Empirical Study of Bosnia and Herzegovina. In J. Ateljević \& J. Trivić (Ed.), Economic Development and Entrepreneurship in Transition Economies (pp. 233-252). Switzerland: Springer.

Petković, S., \& Berberović, Š. (2013). Ekonomika i upravljanje malim i srednjim preduzećima: principi i politike. Banja Luka: Ekonomski fakultet. In Serbian.

Popov, A., \& Roosenboom, P. (2012). Venture capital and patented innovation: Evidence from Europe. Economic Policy, 27(71), 447-482. DOI: 10.1111/j.1468-0327.2012.00290.x.

Ries, E. (2011). The lean startup. United States: Random House.

Romain, A., \& Van Pottelsberghe, B. (2004). The economic impact of venture capital. Retrieved March 5, 2017, from https://www.bundesbank.de/Redaktion/EN/Downloads/Publications/Discussion_Paper_1/2004/2004_08_02_ dkp_18.pdf?_blob=publicationFile.

Romans, A. (2013). The entrepreneurial bible to venture capital: Inside secrets from the leaders in the startup game. New York: McGraw-Hill Education. 
Rosiello, A., Avnimelech, G., \& Teubal, M. (2011). Towards a Systemic and Evolutionary Framework for Venture Capital Policy. In A. Pyka \& M. Derengowski Fonseca (Ed.), Catching Up, Spillovers and Innovation Networks in a Schumpeterian Perspective. Berlin: Springer. DOI: 10.1007/978-3-642-15886-5_9.

Schertler, A. (2006). The venture capital industry in Europe. Basingstoke: Palgrave Macmillan.

Schertler, A., \& Tykvová, T. (2009). Venture capital and internationalization. Mannheim: ZEW.

Schumpeter, J. A. (1975). Capitalism, socialism and democracy. New York: Harper Colophon.

Steingold, F. S. (2006). Legal guide for starting \& running a small business. US: Consolidated printers.

Tobin, L. (2012). Entrepreneur: How to start up your online business. Chichester: Capstone.

Vukmirović, N. (2006). Savremeno preduzetništvo. Banja Luka: Ekonomski fakultet. In Serbian.

Zhang, J. (2007). The advantage of experienced start up founders in venture capital acquisition: Evidence from serial entrepreneurs. Bonn: IZA.

\section{ULOGA POČETNOG KAPITALA U RAZVOJU SEKTORA MALIH I SREDNJIH PREDUZEĆA}

\section{Rezime:}

Preduzetnici, kao i mala i srednja preduzeća, stalno se susreću sa problemom koji se tiče pristupa finansijskim sredstvima. Preduzetničke firme su suočene sa dva glavna problema. Prvi se odnosi na pristup finansijskim sredstvima, što predstavlja dodatno ograničenje na sposobnost date firme da poveća nivo upotrebe tehnologija u svom poslovanju. Drugi problem čini pristup potrebnom tehničkom znanju i veštinama. Predmet ovog istraživanja je uloga fondova početnog kapitala $\mathrm{u}$ razvoju novoosnovanih kompanija i njegova potencijalna primena u Republici Srpskoj. U zemljama engleskog govornog područja, novoosnovana preduzeća koja započinju svoje poslovanje od nule nazivaju se startap kompanijama. Izložena je pretpostavka da finansiranje početnim kapitalom može da pruži novoosnovanim kompanijama veće mogućnosti da uspeju u svojoj početnoj etapi. Poznato je da naše kompanije nabavljaju kapital putem bankarskih kredita koji su u poslednje vreme sve manje dostupni, naročito preduzećima u ranoj etapi razvoja. Stoga, kako bi kompanije dostigle svoje ciljeve i razvile svoje projekte, prinuđene su da finansiraju svoje poslove putem fondova početnog kapitala koji su voljni da investiraju u startap kompanije.

\section{Ključne reči:}

početni kapital, mala i srednja preduzeća, preduzetništvo, zaposlenje, inovacija. 